REPORTS OF MORPHOLOGY
$\begin{gathered}\text { Official Journal of the Scientific Society of Anatomists, } \\ \text { Histologists, Embryologists and Topographic Anatomists } \\ \text { of Ukraine } \\ \text { journal homepage: https://morphology-journal.com }\end{gathered}$

\title{
Histostructural organization of the cerebellum of human fetuses for 8-9 weeks of prenatal development
}

\section{Zalevskiy L.L., Shkolnikov V.S., Prykhodko S.O.}

National Pirogov Memorial Medical University, Vinnytsya, Ukraine

\section{ARTICLE INFO}

Received: 8 July, 2019

Accepted: 7 August, 2019

UDC: $611.817 .1: 616.8-091.94: 618.231$

\section{CORRESPONDING AUTHOR}

e-mail: med2@vnmu.edu.ua Shkolnikov V.S.

\begin{abstract}
The high incidence of anomalies in the hindbrain is due to the fact that neurulation in the cranial compartment lasts the longest time. Therefore, for more detailed study of embryogenesis and understanding of mechanisms of pathogenesis, occurrence of congenital malformations, there is a need to determine the morphometric (histometric) parameters of the cerebellum at different gestational times. The purpose of the study is to determine the morphometric parameters of the cerebellum of human embryos for 89 weeks of prenatal development, as well as features of cytoarchitectonics of its structures, which is inherent in the given gestation period. Anatomo-histological, immunohistochemical and morphometric examination of the cerebellum of 10 human embryos was performed. Serial sections of cerebellum preparations 8-10 microns thick were stained with hematoxylin, eosin, toluidine blue and Van Gieson, and diagnostic monoclonal antibodies of "DacoCytomation" (Denmark): Vimentin, Ki-67 and Synaptophysin were used for immunohistochemical studies. The results of measurements of the total thickness of all layers, the density of neural stem cells (NSC), as well as the area of the right and left hemispheres of the cerebellum were obtained during the study. In immunohistochemical study, we determined the direction of NSC migration and cell proliferation of all layers of the cerebellum, as well as the length of radial glia fibers. In the cerebral hemispheres of embryos of 8-9 weeks there is a clear division into ventricular, intermediate, molecular and outer granular layers. The highest density of neural stem cells was observed in the outer granular layer $151.0 \pm 4.1$ cells per $0.01 \mathrm{~mm}^{2}$. The lowest cell density was observed in the molecular layer $-22.0 \pm 0.8$ cells per $0.01 \mathrm{~mm}^{2}$. The most intense cell proliferation was established in the ventricular layer and the outer granular layer of the cerebellum, and the least intense in the intermediate layer. Synaptophysin expression was only slightly expressed in the ventricular layer of the cerebellum. The radial glial fibers begin from the ventricular layer and penetrate all layers of the cerebellum, ending in the outer granular layer. The average length of radial glial fibers was: short $-120.8 \pm 5.7 \mu \mathrm{m}$, long $-195.3 \pm 9.4 \mu \mathrm{m}$. The exterior granular layer is represented by spherical undifferentiated cells with an average area size of $641.1 \pm 28.9 \mu \mathrm{m}^{2}$, the molecular layer $-N S C$ with an area of $472.9 \pm 23.7 \mu \mathrm{m}^{2}$, the intermediate layer - NSC with an area of $492.2 \pm 23.1 \mu \mathrm{m}^{2}$, and the ventricular layer is represented by neuroblasts with an area of $436.1 \pm 21.8 \mu \mathrm{m}^{2}$. Thus, it is established that there is a clear division of the cerebellum layers into the ventricular layer, which is represented by neuroblasts, the intermediate layer - NSC, the molecular layer-NSC, and the outer granular layer is represented by undifferentiated cells; the densest neural stem cells are located in the outer granular layer and less densely in the molecular layer. Key words: cerebellum, morphometric parameters, radial glia, prenatal development.
\end{abstract}

\section{Introduction}

Anatomic and physiological integration is evaluated as a unit of a functional system that unites in one adaptive reaction each specific case and the dynamics of nervous processes. In particular, the fetus is characterized by the acceleration and selective development of those structures of the central nervous system (CNS), as well as those functions that will be required for the newborn in order to exercise the basic types of vital activity $[4,9,19]$.

The process of nerve tube formation begins from 22-23 days and ends between 25-27 days. It is known that 
abnormalities in the development of the CNS result from the influence of environmental and genetic factors, but the mechanisms of pathogenesis of embryonic abnormalities of human brain development are still unknown [2, 7, 13].

Disruption of CNS formation and localization of malformation in early gestation depends on the timing and arrest of the stages of neurulation. The high incidence of anomalies of the spinal, medulla, and hindbrain is due to the fact that neurulation in the cranial compartment lasts the longest period of time. During the closure of the medullary rollers, the basis of the driving factor of morphogenesis is the intercellular interaction, which determines the formation of the brain and in violation of which irreversible abnormalities of the CNS develop [10, 14, 17, 23].

The human brain develops from tubular structures, but the morphological organization is very complex. During prenatal development, structural changes occur in the brain and the basic elements of the definitive brain are formed. At various stages of prenatal development, a detailed topographic-histological examination of the human brain will not only help in understanding the highly ordered process of its structure, but also help to identify developmental defects that are related to genetic or environmental factors $[5,8,11,15,18,22]$.

Thus, a detailed study of the cerebellum of the fetus and human embryos in different periods of prenatal development makes it possible to establish certain patterns of restructuring of its structure.

The purpose of the study is to determine the morphometric parameters of the cerebellum of human embryos for 8-9 weeks of prenatal development, as well as features of cytoarchitectonics of its structures, which is inherent in the given gestation period.

\section{Materials and methods}

The work is a fragment of the planned scientific work of the Department of Human Anatomy, National Pirogov Memorial Medical University, Vinnytsya "Determination of morphological changes of the central nervous system of a person during the prenatal period of ontogeny (macroscopic, histological, morphometric, immunohistochemical study)", state registration № 0118 U001043.

Anatomic-histological, immunohistochemical and morphometric examination of the cerebellum of 10 human embryos was performed for 8-9 weeks. The parietal-coccygeal length was $34.0 \pm 1.7 \mathrm{~mm}$, the mass was $5.0 \pm 0.7 \mathrm{~g}$. The materials were obtained as a result of a late abortion at the Vinnitsa Regional Pathological Office. Defects of the CNS development in this period were absent. The fixation of the preparations of the cerebellum was performed according to own technique [20].

Subsequently, serial sections of cerebellar preparations 8-10 $\mu \mathrm{m}$ thick were made, stained with hematoxylin, eosin, toluidine blue and Van Gieson. Diagnostic monoclonal antibodies from "DacoCytomation"
(Denmark) were used in immunohistochemical studies: Vimentin, Ki-67 and Synaptophysin. Ki-67 was used to evaluate the proliferative activity of neural stem cells (NSC), Vimentin - to investigate the morphology of radial glia and Synaptophysin - to evaluate the myelination of the fibers of the leading pathways and to establish their connections.

SIGETA and MBS-10 light microscope was used for morphometric examination. Magnification x4, x10, x20, x40 and $\mathrm{x} 100$ were used. Photographs and morphometry of the obtained sections were performed using an ETREK Ucmos camera and a ToupView computer program (computer histometry).

Statistical processing of digital data was carried out using the standard software package "Statistica 6.0 " by Statsoft (license number BXXR901E246122FA).

\section{Results}

In the course of the study we obtained the following morphometric parameters of the structures of the cerebellum: the total thickness of all layers of the right cerebellum hemisphere was $1675 \pm 79 \mu \mathrm{m}$, the externally granular layer - $28.20 \pm 1.20 \mu \mathrm{m}$, the molecular layer $20.62 \pm 1.02 \mu \mathrm{m}$, the intermediate layer - $1590 \pm 74 \mu \mathrm{m}$, ventricular layer $-36.30 \pm 1.70 \mu \mathrm{m}$.

In the study of the thickness of all layers of the left cerebellum hemisphere, the following data were obtained - $1643 \pm 76 \mu \mathrm{m}$, externally granular layer $-28.00 \pm 1.20 \mu \mathrm{m}$, molecular layer - $20.10 \pm 1.00 \mu \mathrm{m}$, intermediate layer $1559 \pm 75 \mu \mathrm{m}$, ventricular layer - $36.20 \pm 1.80 \mu \mathrm{m}$ (Fig. 1). The greatest thickness was observed in the intermediate layer, whereas the molecular layer had the lowest thickness (Fig. 2).

The density of NSCs in the ventricular layer of all structures of both hemispheres was $134.0 \pm 3.9$ cells per $0.01 \mathrm{~mm}^{2}$. In the outer granular layer (neurons and gliocytes) - $151.0 \pm 4.1$ cells per $0.01 \mathrm{~mm}^{2}$. In the intermediate layer $74.00 \pm 3.00$ cells per $0.01 \mathrm{~mm}^{2}$. The lowest cell density was visualized in the molecular layer $-22.00 \pm 0.80$ cells per $0.01 \mathrm{~mm}^{2}$. Thus, we found that the lowest cell density was observed in the molecular layer $-22.00 \pm 0.70$ cells per $0.01 \mathrm{~mm}^{2}$, whereas the highest cell density was observed in the outer granular layer - $151.0 \pm 4.2$ cells per $0.01 \mathrm{~mm}^{2}$ (Fig. 3).

In the outer granular layer are represented by spherical undifferentiated cells with an area of $641.1 \pm 28.9 \mu \mathrm{m}^{2}$, the molecular layer is represented by NSC area of $472.9 \pm$ $23.7 \mu \mathrm{m}^{2}$, the intermediate layer of NSC $492.2 \pm 23.1 \mu \mathrm{m}^{2}$, the ventricular layer is represented by neuroblasts with an area of $436.1 \pm 21.8 \mu \mathrm{m}^{2}$.

At 8-9 weeks of gestation NSC migration takes place in the radial direction and the externally granular layer tangentially.

Cell proliferation occurs more intensively in the ventricular layer, as well as in the outer granular layer of the cerebellum, less intensively in the intermediate layer (Fig. 4). 


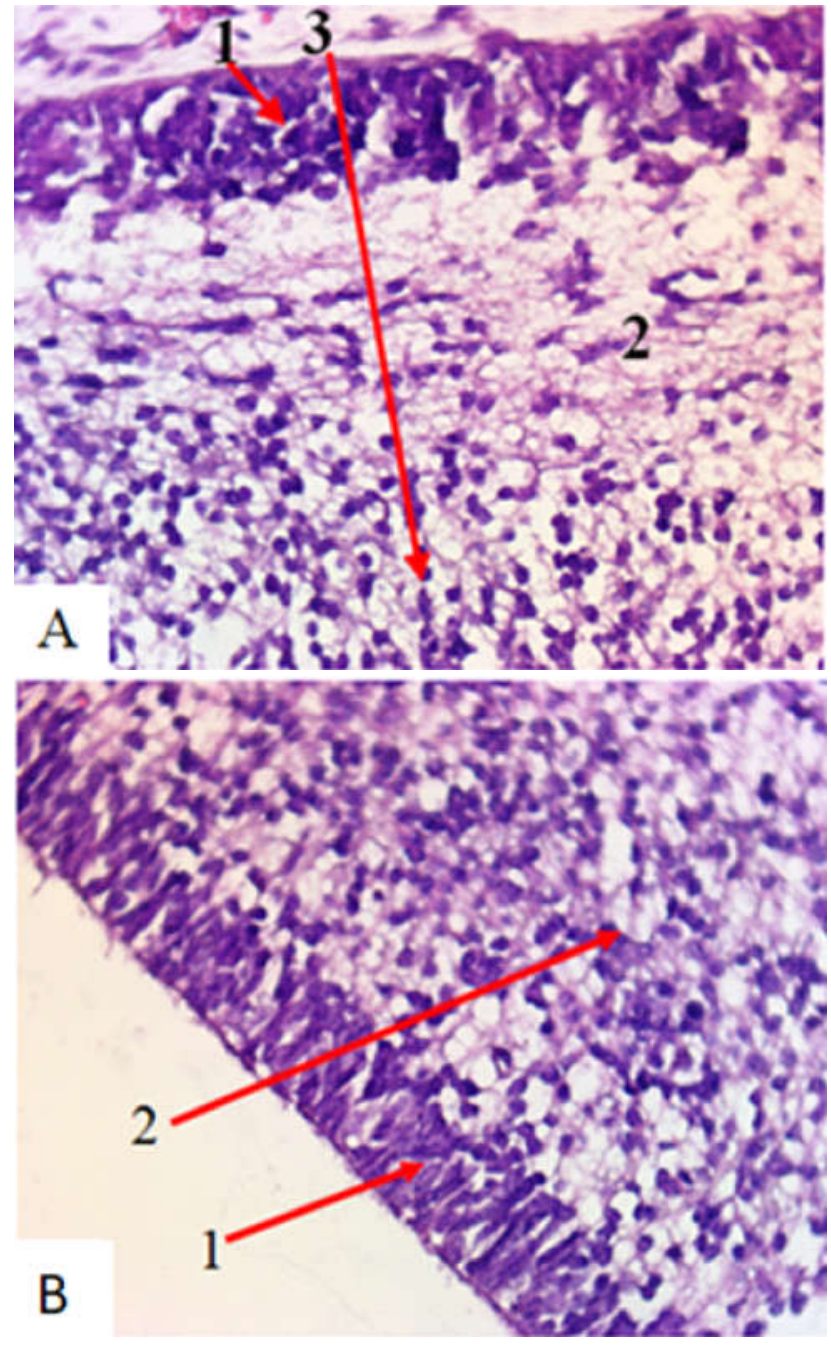

Fig. 1. Human fetal cerebellum at 8-9 weeks. A- horizontal crosssection of the cerebellum: 1 - outer granular layer, 2 - molecular layer, 3 - intermediate layer. Hematoxylin-eosin; x400. B - horizontal section of the cerebellum: 1 - ventricular layer, 2 - intermediate layer. Hematoxylin-eosin, x400.

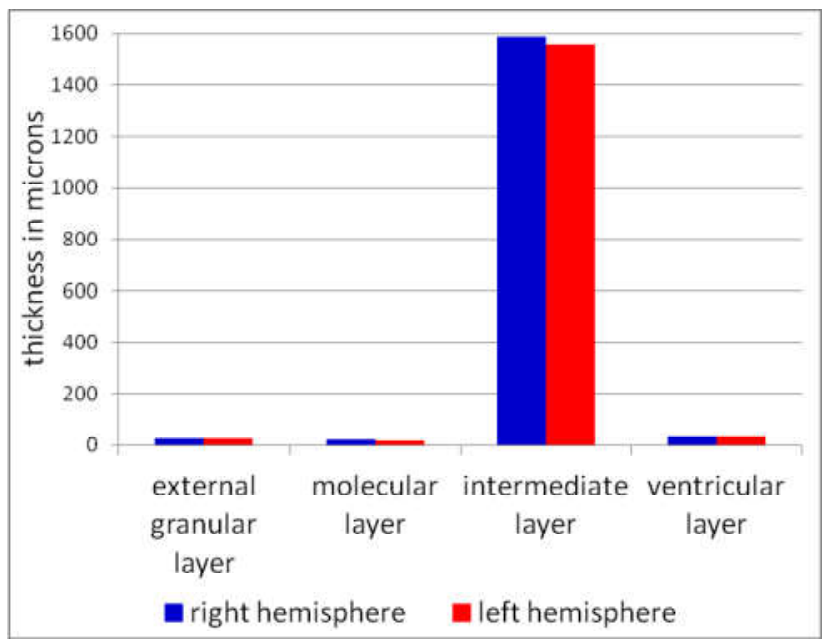

Fig. 2. The thickness of the layers of the cerebellum of an 8-9 weeks human embryo.

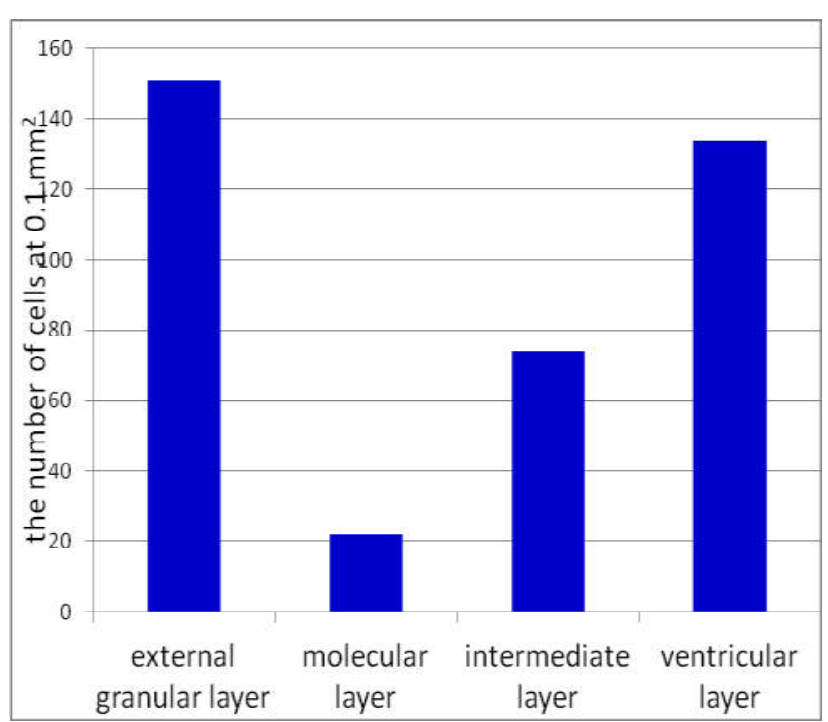

Fig. 3. The density of NSC in the layers of the cerebellum of 8-9 weeks human embryo.

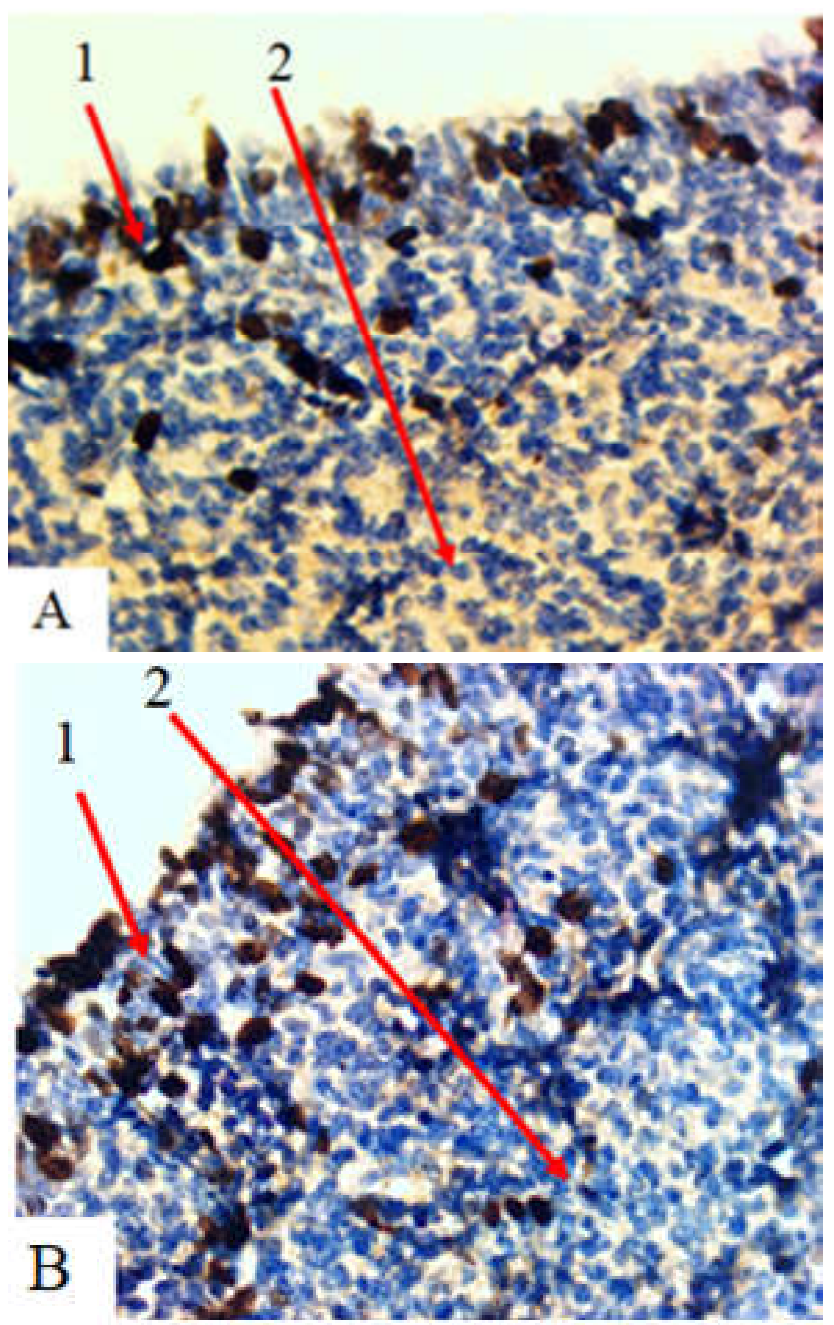

Fig. 4. Proliferation in cerebellar hemispheres at 8-9 weeks. A: 1 ventricular layer, 2 - intermediate layer. Ki-67, x400. B: 1 - outer granular layer, 2 - intermediate layer. Ki-67, x400. 

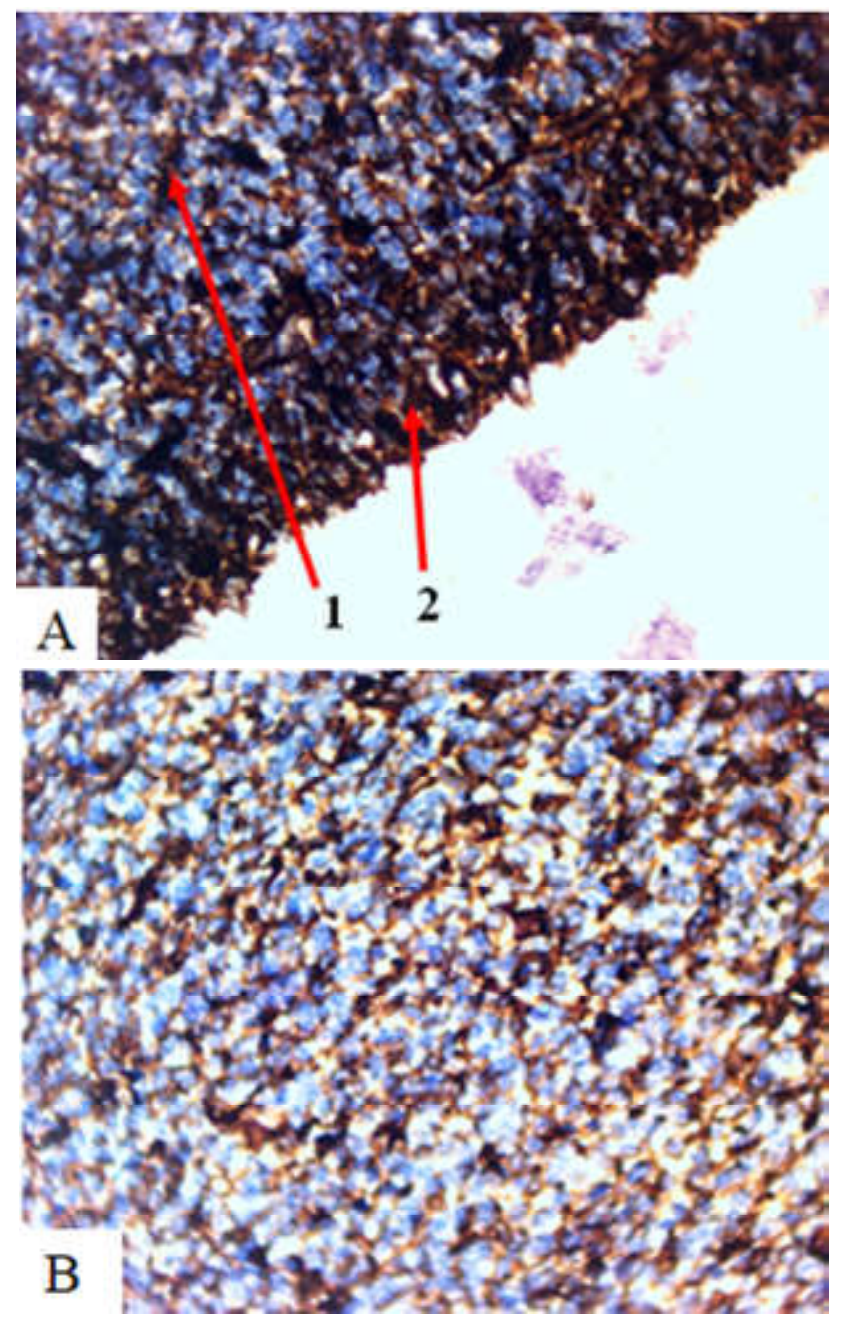

Fig. 5. Horizontal slice of the cerebellum. A: 1 - intermediate layer, 2 - ventricular layer. Vimentin; x400. B - intermediate layer. Vimentin; $\mathrm{x} 400$.

We have found that when using Vimentin, radial glial fibers start from the ventricular layer, penetrate all layers of the cerebellum in the radial direction and end in the externally granular layer. The expression of Vimentin in radial glial fibers was relatively moderate in the intermediate layer and relatively strong in the ventricular and externally granular layers. The average length of radial glial fibers was: short 120.8 $\pm 5.7 \mu \mathrm{m}$, long - 195.3 $\pm 9.4 \mu \mathrm{m}$ (Fig. 5).

The expression of Synaptophysin in this term is slightly expressed in all layers of the cerebellum (Fig. 6).

Thus, in the course of the study we established the features of cytoarchitectonics, morphometric parameters of the structures of the cerebellum of human cerebellum embryos at 8-9 weeks of prenatal development.

\section{Discussion}

Owing to the expansion of the wall of the cranial end of the nerve tube in the region of the hindbrain, the cerebellum is formed [21].

When examining histological sections, we observed
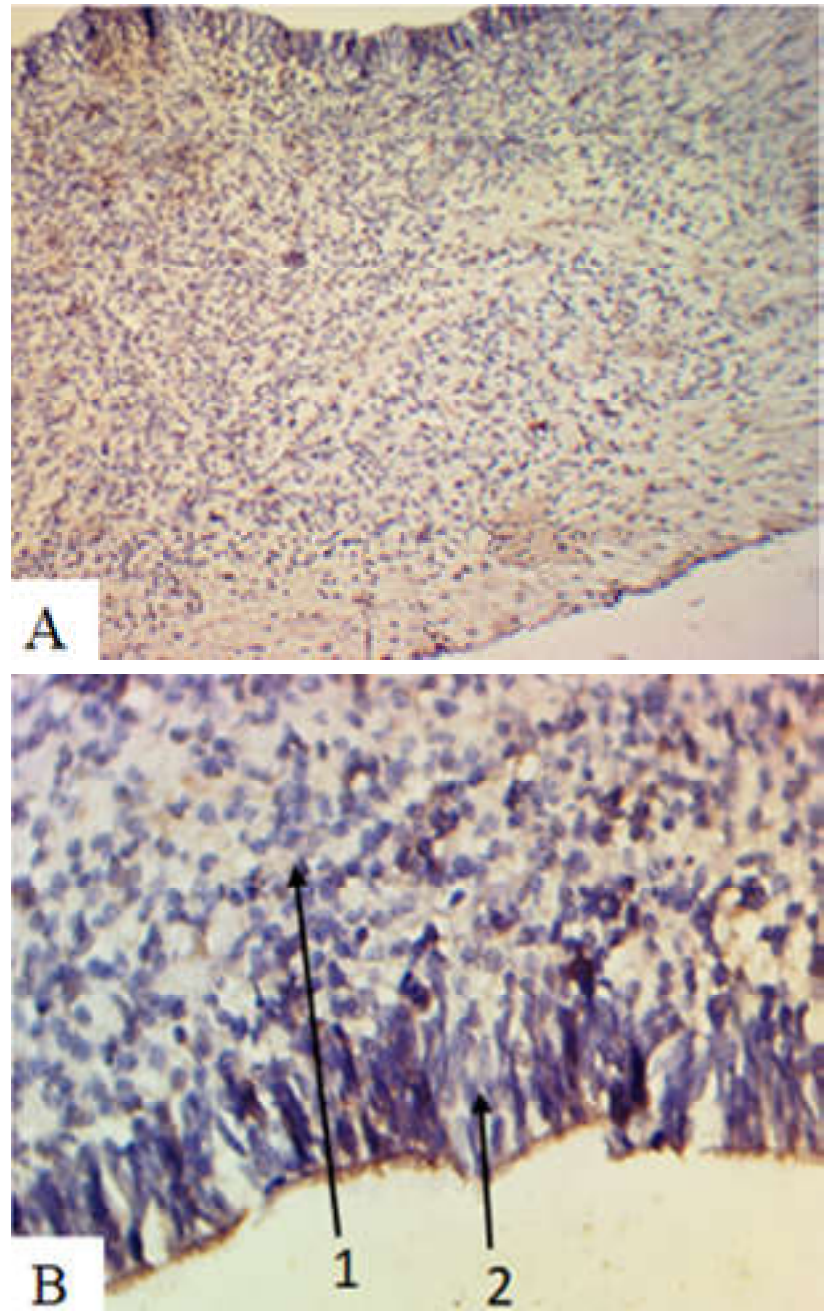

Fig. 6. Horizontal slice of cerebral hemispheres. A: Synaptophysin; x100. B: 1 - ventricular layer, 2 - intermediate layer. Synaptophysin, $\mathrm{x} 400$.

that during this period from the formed hemisphere of the cerebellum over the fourth ventricle, the formation of the cerebellar worm occurs, whereas K. Cho (2011) indicates that at the end of the embryonic period and at the beginning of the fetal period, starting from 7-8 weeks, the rhombic lip and the alar plate expanded to form the cerebellar hemispheres that began to approach over the fourth ventricle. The cerebellar worm forms a little later, up to 10 weeks. The cerebellar worm forms a little later, by 10 weeks the cerebellar hemispheres have already merged along the median line, forming the cerebellar worm [3].

Thus, we found that the lowest cell density was observed in the molecular layer - $22.00 \pm 0.70$ cells per $0.01 \mathrm{~mm}^{2}$, whereas the highest cell density was observed in the outer granular layer - $151.0 \pm 4.2$ cells per $0.01 \mathrm{~mm}^{2}$. In our opinion, this phenomenon is related to the fact that NSC migrates from the outer granular layer towards the ventricular layer to form the inner granular layer, whereas J. Volpe (2009) states that the tabulation of Purkinje nuclei and cells occurs in the first weeks of development of 
migration of neuroblasts in the ventricular layer. During the period of 9-10 weeks of prenatal development, neural stem cells are separated from the ependymal layer of the fourth ventricle and migrate to the surface of the cerebellum (primary migration). Thus, they form the outer germinal layer, and by the 21 st week its thickness is 6-9 cell layers. Hence, cells differentiate into neuroblasts and migrate in the opposite direction. The movement of cells through the Purkinje cell layer is directed by radial glia $[6,16,21]$.

At 8-9 weeks gestation NSC migration takes place in the radial direction, and the outer granular layer tangentially, as J. Volpe points out [21], NSC migration in the fetal period occurs in the radial direction, and in the embryonic period, the outward granular layer is formed where the cells go tangential direction above the surface of the cerebellum.

Cell proliferation occurs more intensely in the ventricular layer as well as in the outer granular layer of the cerebellum, however, H. Abrahám (2001) found that expression of Ki-67 in the cerebral cortex of a human fetus for 24 weeks of prenatal development more intense in the outer granular layer [1].

The expression of Synaptophysin in this term is slightly expressed in all layers of the cerebellum, whereas $A$. Milosevic in 1998 indicates that for 13 weeks, the expression of Synaptophysin is present in all layers of the cerebellum [12]. In our view, Synaptophysin expression is insignificantly expressed in all layers, which may be due to the fact that in this embryonic period the fetus is not as active as in 13 weeks of prenatal development.

Prospects for further development are to study the patterns of development and establishment of structures of the human cerebellum during the prenatal development, as well as the subsequent use of immuno-histochemical

\section{References}

[1]Abrahám, H., Tornóczky, T., Kosztolányi, G., \& Seress, L. (2001). Cell formation in the cortical layers of the developing human cerebellum. Int. J. Dev. Neurosci, 19, 53-62. doi: 10.1016/ s0736-5748(00)00065-4

[2] Antipkin, Y. G., Kirilova, L. G., Avramenko, T. V., \& Shevchenko, O.A. (2015). Congenital malformations of the CNS: the current state of the problem, clinical and neurological features and issues of optimization of prenatal diagnosis. Journal of the National Academy of Medical Sciences of Ukraine, 21(2), 201-214.

[3] Cho, K. H. (2011). Early fetal development of the human cerebellum. Surg. Radiol. Anat., 33(6), 523-530. doi: 10.1007/ s00276-011-0796-8.

[4] Dastjerdi, F. V., Consalez, G. G., \& Hawkes, R. (2012). Pattern formation during development of the embryonic cerebellum. Front. Neuroanat., 10(6). doi: 10.3389/fnana.2012.00010

[5] Fei, L., Zhonghe, Z., Xiangtao, L., Gaojun, T., Haiwei, M., Taifei, Y. ... Shuwei, L. (2011). Development of the human fetal cerebellum in the second trimester: a post mortem magnetic resonance imaging evaluation. Anat., 219(5), 582-588. doi: 10.1111/j.1469-7580.2011.01418.x

[6] Hassan, M., Marc, R. D. B., Javad, A., Saeid, G., Robby, M. Z., \& Mojgan, R. (2015). Cellular commitment in the developing cerebellum. Front. Cell. Neurosci. doi.org/10.3389/ fncel.2014.00450 markers to conduct a comprehensive study and comparative analysis of similar indicators of human embryos and fetuses.

\section{Conclusions}

1. In the cerebellar hemispheres of embryos, 8-9 weeks of prenatal development, there is a clear division into ventricular, intermediate, molecular and outer granular layers. It was found that the densest NSC are located in the outer granular layer $\left(151.0 \pm 4.1\right.$ cells per $\left.0.01 \mathrm{~mm}^{2}\right)$ and less densely in the molecular layer $(22.00 \pm 0.80$ cells per $0.01 \mathrm{~mm}^{2}$ ). The greatest thickness had an intermediate layer of the cerebellum - $1574 \pm 83 \mu \mathrm{m}$, the smallest - molecular layer $20.30 \pm 1.00 \mu \mathrm{m}$.

2. Relatively most intense cell proliferation was found in the ventricular layer and the outer granular layer of the cerebellum and the least intense in the intermediate layer. Synaptophysin expression is slightly expressed in the ventricular layer of the cerebellum.

3. It is established that the radial glial fibers start from the ventricular layer, permeate all layers of the cerebellum and end in the outer granular layer. The expression of Vimentin in radial glia fibers is relatively moderate in the intermediate layer and relatively strong in the ventricular and external granular layers. The average length of radial glial fibers was: short - 120.8 $\pm 5.7 \mu \mathrm{m}$, long - 195.3 $\pm 9.4 \mu \mathrm{m}$.

4. The exterior granular layer is represented by spherical undifferentiated cells with an area of $641.1 \pm 28.9 \mu \mathrm{m}^{2}$, the molecular layer is represented by NSC area $472.9 \pm$

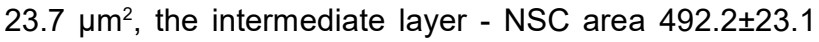
$\mu \mathrm{m}^{2}$, the ventricular layer is represented by neuroblasts with an area of $436.1 \pm 21.8 \mu \mathrm{m}^{2}$.

[7] Hibi, M., \& Shimizu, T. (2012). Development of the cerebellum and cerebellar neural circuits. Dev. Neurobiol., 72, 282-301. doi: 10.1002/dneu.20875

[8] Huang, H. (2010). Structure of the fetal brain: what we are learning from diffusion tensor imaging. The Neuroscientist, 16, 634-649. doi: 10.1177/1073858409356711

[9] Hutchins, B., Klenke, U., \& Wray, S. (2013). Calcium releasedependent actin flow in the leading process mediatesaxophilic migration. J. Neurosci., 33, 11361-11371. doi: 10.1523/ JNEUROSCI.3758-12.2013

[10] Marklund, U., Alekseenko, Z., Andersson, E., Falci, S., Westgren, M., Perlmann, T. ... Ericson, J. (2014). Detailed Expression Analysis of Regulatory Genes in the Early Developing Human Neural Tube. Stem Cells Dev., 23(1), 5-15. doi: 10.1089/ scd.2013.0309

[11] Martinez, S., Andreu, A., Mecklenburg, N., \& Echevarria, D. (2013). Cellular and molecular basis of cerebellar development. Neuroanat. doi.org/10.3389/fnana.2013.00018

[12] Milosevic, A. (1998). Developmental changes in human cerebellum: Expression of intracellular calcium receptors, calcium binding proteins, and phosphorylated and nonphosphorylated neurofilament protein. Zecevic Version of Record online, 10(2), 442-460. doi: 10.1002/(SICI)10969861(19980713)396

[13] Mohammed, H. K., Abubaker, E., Deya, E. A. M., \& Khalid, T. 
(2015). Sonographic Evaluation of Normal Anatomy of Fetal Central Nervous System in Mid-Trimester. Forensic Medicine and Anatomy Research., 3(1) 32-38. doi.org/10.4236/ fmar.2015.31007

[14] Nowakowska-Kotas, M., Kedzia, A., \& Dudek, K. (2014). Development of external surfaces of human cerebellar lobes in the fetal period. Cerebellum., 13, 541-548. doi: 10.1007/ s12311-014-0566-3

[15] Ostrem, B. E., Lui, J. H., Gertz, C. C., \& Kriegstein, A. R. (2014). Control of outer radial glial stem cell mitosis in the human brain. Cell. Rep., 7, 8(3), 656-664. doi: 10.1016/j.celrep.2014.06.058

[16] Rakic, P., \& Sidman, L. (1970). Histogenesis of cortical layers in human cerebellum, particularly the lamina dissecans. Comp. Neurol., 139(4), 473-500. doi: 10.1002/cne.901390407

[17] Saveliev, S. V. (2012). Pathology of embryonic morphogenesis of the human brain. Bulletin of the Russian Academy of Medical Sciences, 8, 40-46.

[18] Shiraishi, N., Katayama, A., Nakashima, T., Yamada, S., Uwabe, C., Kose, K., \& Takakuwa, T. (2015). Three-dimensional morphology of the human embryonic brain. Data Brief., 4,
116-118. doi: 10.1016/j.dib.2015.05.001

[19] Shkolnikov, V. S. (2015). Macro- and microstructure of the spinal cord of human fetuses with teratomas. Reports of Morphology, 21(1), 117-127.

[20] Shkolnikov, V. S., Zalevsky, L. L., Stelmashchuk, P. A., Tikholaz, V. O., Gryshchenko, Y. V. (2017). Patent of Ukraine № 115849 МПКА61В 17/00, А61В 17/06 (2006.01)

[21] Volpe, J. (2009). Cerebellum of the premature infant: rapidly developing, vulnerable, clinically important. Child. Neurol., 24(9), 1085-1104. doi: 10.1177/0883073809338067

[22] Williams, J., Mai, C., Mulinare, J., Isenburg, J., Flood, T. J., Ethen, M. ... Kirby, R. S. (2015). Updated estimates of neural tube defects prevented by mandatory folic Acid fortification United States, 1995-2011. MMWR Morb. Mortal. Wkly Rep., 64(1), 1-5.

[23] Xu, H., Yang, Y., Tang, X., Zhao, M., Liang, F., Xu, P. ... Fan, X. (2013). Bergmann glia function in granule cell migration during cerebellum development. Mol. Neurobiol, 47, 833-844. doi: 10.1007/s12035-013-8405-y

\section{ГІСТОСТРУКТУРНА ОРГАНІЗАЦІЯ МОЗОЧКА ЕМБРІОНІВ ЛЮДИНИ 8-9 ТИЖНІВ ВНУТРІШНЬОУТРОБНОГО РОЗВИТКУ}

\section{Залевський Л.Л., Школьніков В.С., Приходько С.О.}

Висока частота розповсюдженості аномалій заднього мозку обумовлена тим, що нейруляція у краніальному відділі триває найбільший проміжок часу. Тому, для більш детального дослідження ембріогенезу, розуміння механізмів патогенезу та виникнення вроджених вад розвитку виникає необхідність у визначенні морфометричних (гістометричних) параметрів мозочка у різні терміни гестації. Мета дослідження - встановити морфометричні параметри мозочка ембріонів людини 8-9 тиж. внутрішньоутробного розвитку, а також особливості цитоархітектоніки його структур, яка притаманна для даного терміну гестації. Проведено анатомо-гістологічне, імуногістохімічне та морфометричне дослідження мозочка 10 ембріонів людини. Виготовляли серійні зрізи препаратів мозочку товщиною 8-10 мкм, які забарвлювали гематоксиліном, еозином, толуїдиновим синім та за Ван-Гізон. Для імуногістохімічного дослідження були використані діагностичні моноклональні антитіла форми "DacoCytomation" (Данія): віментин, Кі-67 та синаптофрізин. У ході дослідження отримані результати вимірів загальної товщини усіх шарів, щільність нейральних стовбурових клітин (НСК), а також площі правої та лівої півкуль мозочка. При імуногістохімічному дослідженні визначили напрямок міграції НСК та проліфрерацію клітин усіх шарів мозочка, а також довжину волокон радіальної глії. У півкулях мозочка ембріонів 8-9 тижня відбувається чіткий поділ на вентрикулярний, проміжний, молекулярний і зовнішній

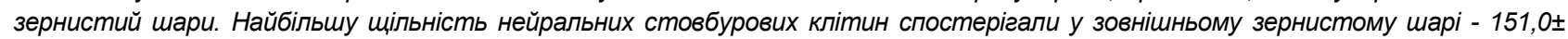

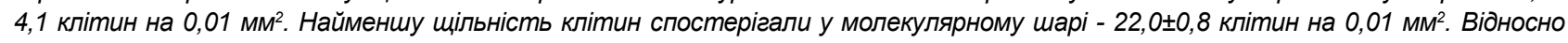
найбільш інтенсивну проліферацію клітин встановили у вентрикулярному шарі та зовнішньому зернистому шарі мозочка, найменш інтенсивну - у проміжному шарі. Експресія синаптофізину була виражена незначно у вентрикулярному шарі мозочка. Волокна радіальної глії починаються від вентрикулярного шару та пронизують усі шари мозочка, закінчуючись у зовнішньому

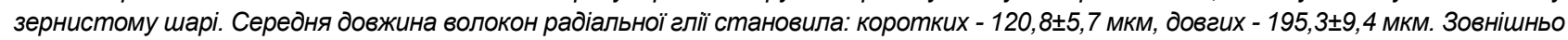
зернистий шар представлений кулястими недиференційованими клітинами середнім розміром площі 641,1士28,9 мкм², молекулярний

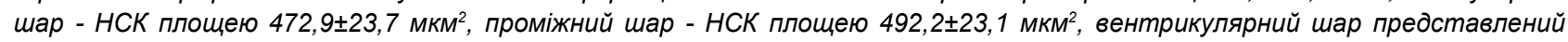

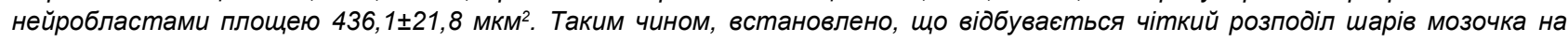
вентрикулярний шар, який представлений нейробластами, проміжний шар - НСК, молекулярний шар - НСК, а зовнішній зернистий шар представлений недиферениійованими клітинами; найщільніше нейральні стовбурові клітини розташовуються у зовнішньому зернистому шарі, а менш щільно - у молекулярному шарі.

Ключові слова: мозочок, морфометричні параметри, радіальна глія, внутрішньоутробний розвиток.

\section{ГИСТОСТРУКТУРНАЯ ОРГАНИЗАЦИЯ МОЗЖЕЧКА ЭМБРИОНА ЧЕЛОВЕКА 8-9 НЕДЕЛЬНОГО ВНУТРИУТРОБНОГО РАЗВИТИЯ \\ Залевский Л.Л., Школьников В.С., Приходько С.А.}

Высокая частота распространенности аномалий заднего мозга обусловлена тем, что нейруляция в краниальном отделе продолжается длительный период времени. Поэтому, для более подробного исследования эмбриогенеза, понимания механизмов патогенеза и возникновения врожденных пороков развития возникает необходимость в определении морфометрических (гистометрических) параметров мозжечка в разные сроки гестации. Цель исследования - установить морфометрические параметры мозжечка эмбрионов человека 8-9 нед. внутриутробного развития, а также особенности цитоархитектоники его структур, которая характерна для данного срока гестации. Проведено анатомо-гистологическое, иммуногистохимическое и морфометрическое исследования мозжечка 10 эмбрионов человека. Изготавливали серийные срезы препаратов мозжечка толщиной 8-10 мкм, которые окрашивали гематоксилином, эозином, толуидиновым синим и по Ван-Гизону. Для иммуногистохимического исследования были использованы диагностические моноклональные антитела фрирмы "DacoCytomation" (Дания): виментин, Ки-67 и синаптофизин. В процессе исследования нами были получены результаты измерений общей толщины всех слоев, плотность нейральных стволовых клеток (НСК), а также площадь правого и левого полушарий мозжечка. При иммуногистохимическом исследовании определили направление миграции НСК и 
пролиферацию клеток всех слоев мозжечка, а также длину волокон радиальной глии. В полушариях мозжечка эмбрионов 89 недели происходит четкое разделение на вентрикулярный, промежуточный, молекулярный и внешний зернистый слои. Наибольшую плотность нейральных стволовых клеток наблюдали во внешнем зернистом слое - 151,0 4,1 клеток на 0,01

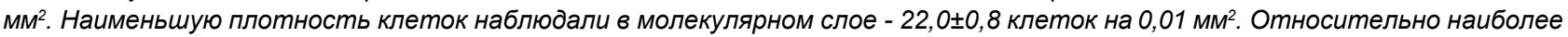
интенсивную пролиферацию клеток установили в вентрикулярном слое и внешнем зернистом слое мозжечка, а наименее интенсивную - в промежуточном слое. Экспрессия синаптофризина была незначительно выражена в вентрикулярном слое мозжечка. Волокна радиальной глии начинаются от вентрикулярного слоя и пронизывают все слои мозжечка, заканчиваясь во внешнем зернистом слое. Средняя длина волокон радиальной глии составила: коротких - 120,8 5,7 мкм, длинных 195,3ะ9,4 мкм. Внешний зернистый слой представлен шаровидными недиффреренцироваными клетками средним размером

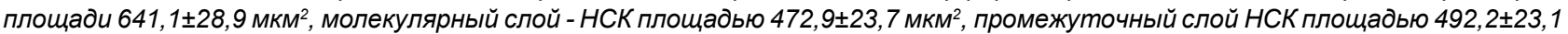

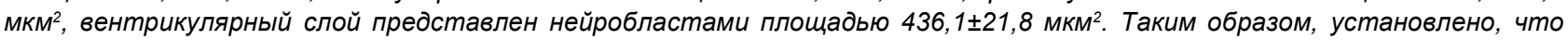
происходит четкое разделение слоев мозжечка на вентрикулярний слой, который представлен нейробластами, промежуточный слой - НСК, молекулярный слой - НСК, а внешний зернистый слой представлен недифрференцированными клетками; более плотно нейральные стволовые клетки располагаются во внешнем зернистом слое, а менее плотно - 8 молекулярном слое.

Ключевые слова: мозжечок, морфометрические параметры, радиальная глия, внутриутробное развитие. 